\title{
Optimization of total anthocyanin content and antioxidant activity of a Hibiscus sabdariffa infusion using response surface methodology
}

\author{
Optimización del contenido de antocianinas y capacidad antioxidante de una infusión de \\ Hibiscus sabdariffa con metodología de superficie de respuesta
}

\begin{abstract}
Mayra L. Salmerón-Ruiz', J. Abraham Domínguez-Avila², J. Fernando Ayala-Zavala', Emilio Alvarez-Parrilla ${ }^{3}$, Mónica A. Villegas-Ochoa', Sonia Guadalupe Sáyago-Ayerdi', Martín Valenzuela-Melendez y Gustavo A. González-Aguilar*

1 Centro de Investigación en Alimentación y Desarrollo A. C. Carretera Gustavo Enrique Astiazarán Rosas No. 46 Colonia La Victoria CP 83304. Hermosillo, Sonora, México.

2 Cátedras CONACYT-Centro de Investigación en Alimentación y Desarrollo A. C. Carretera Gustavo Enrique Astiazarán Rosas No. 46 Colonia La Victoria CP 83304. Hermosillo, Sonora, México.

3 Universidad Autónoma de Ciudad Juárez. Anillo Envolvente del PRONAF y Estocolmo S/N. CP 32315. Ciudad Juárez, Chihuahua, México.

4 Instituto Tecnológico de Tepic. Av. Tecnológico \# 2295 Lagos del Country CP 63175. Tepic, Nayarit, México.
\end{abstract}

\section{ABSTRACT}

Hibiscus sabdariffa L. calyces are underutilized sources of health-promoting anthocyanins. Infusions are the most common way to consume them, but because anthocyanins are thermosensitive, prolonged extraction times at high temperatures may reduce their bioactivities, suggesting the need to identify optimal preparation conditions. Response surface methodology was used to establish calyces-to-water ratio $\left(X_{1}\right.$ : $1-20 \mathrm{~g} / 100 \mathrm{~mL})$, temperature $\left(X_{2}: 70-100{ }^{\circ} \mathrm{C}\right)$, and time $\left(X_{3}\right.$ : 1-30 min) that would produce an infusion with optimized total anthocyanin content (TAC) and antioxidant activity. Under optimum conditions $\left(X_{1}=10 \mathrm{~g} / 100 \mathrm{~mL}, X_{2}=88.7^{\circ} \mathrm{C}\right.$, and $\mathrm{X}_{3}=15.5 \mathrm{~min}$ ) TAC was $132.7 \pm 7.8 \mathrm{mg}$ cyanidin-3-glucoside equivalents $(\mathrm{C} 3 \mathrm{G}) / 100 \mathrm{~mL}$, and antioxidant activity was 800.6 \pm 69.9 (DPPH assay), and 1792.0 \pm 153.5 (ABTS assay) $\mu \mathrm{mol}$ Trolox equivalents (TE)/100 mL. Predicted and experimental results were statistically similar. Identifying ideal processing conditions can promote consumption of an $H$. sabdariffa-based functional beverage with high anthocyanin content and antioxidant activity that exert health-promoting bioactivities on the consumer.

Keywords: Hibiscus, Roselle, Anthocyanin, Antioxidant, Response surface methodology.

\section{RESUMEN}

Los cálices de Hibiscus sabdariffa L. son fuentes poco utilizadas de antocianinas con efectos promotores a la salud. Las infusiones son la manera más común de consumirlas, pero debido a que las antocianinas son termosensibles, tiempos de extracción prolongados a altas temperaturas pueden reducir su bioactividad, lo cual sugiere la necesidad de identificar condiciones óptimas de preparación. Se utilizó metodología de superficie de respuesta para establecer la proporción de cálices-agua $\left(X_{1}: 1-20 \mathrm{~g} / 100 \mathrm{~mL}\right)$, temperatura $\left(X_{2}: 70-100^{\circ} \mathrm{C}\right)$, y tiempo $\left(X_{3}: 1-30 \mathrm{~min}\right)$ que producen una infusión con contenido de antocianinas totales (CAT) y actividad antioxidante optimizados. Bajo condiciones óptimas $\left(X_{1}=10\right.$ $\mathrm{g} / 100 \mathrm{~mL}, X_{2}=88.7{ }^{\circ} \mathrm{C}$, and $X_{3}=15.5 \mathrm{~min}$ ) CAT fue $132.7 \pm 7.8$ mg equivalentes de cianidina-3-glucósido (C3G)/100 mL, y capacidad antioxidante fue $800.6 \pm 69.9$ (ensayo DPPH), y $1792.0 \pm 153.5$ (ensayo ABTS) $\mu$ mol equivalentes de Trolox (ET)/100 mL. Los resultados predichos y experimentales fueron estadísticamente similares. El identificar las condiciones de procesamiento adecuadas puede promover el consumo de una bebida funcional a base de $H$. sabdariffa con alta CAT y capacidad antioxidante que ejerzan bioactividades promotoras a la salud del consumidor.

Palabras clave: jamaica, antocianinas, antioxidantes, metodología de superficie de respuesta.

\section{INTRODUCTION}

The calyces of the Hibiscus sabdariffa L. plant (also known as roselle) are used to prepare infusions, but they can also be cooked, or used as components in herbal supplements (Ali et al., 2005). They have a very intense dark red tonality, which is due to a high concentration of polyphenolic compounds. The main class of compounds present are anthocyanins, specifically, various glucosides of cyanidin and delphinidin (Grajeda-Iglesias et al., 2016). Anthocyanins in general are highly bioactive compounds, and their intake from $H$. sabdariffa infusions has been shown to elicit a positive impact on the consumer's health. For example, a meta-analysis concluded that $H$. sabdariffa can significantly decrease systolic and diastolic blood pressure in hypertensive subjects (Serban et al., 2015). Others have demonstrated an antitumoral effect against different cancerous cells of human origin, and their effects on a rat model of chronic kidney disease were similar to pharmacological antihypertensives (Ali et al., 2017, Chiu et al., 2015, Malacrida et al., 2016). Although antioxidant activity is a defining characteristic of anthocyanins, their actions on the consumer seem to extend beyond this in vitro parameter once they reach various tissues. Thus, the need arises to study the different variables that may alter their concentration and bioactivity.

When preparing an infusion, the method used should ideally extract all, or at least the majority of the available

*Autor para correspondencia: Gustavo A. González Aguilar Correo electrónico: gustavo@ciad.mx

Recibido: 12 de junio de 2018

Aceptado: 6 de septiembre de 2018 
anthocyanins, without any losses or changes in their molecular structure that could compromise their subsequent bioactivity. But since traditional methods are regularly used, the final product may not be the most optimal. Among the variables that have the most impact are the solid-to-solvent (i.e. calyces-to-water) ratio, water temperature, and infusion time. A lower solid-to-solvent ratio will allow a higher extraction efficiency, but it may require a longer time; and on the contrary, a higher solid-to-solvent ratio may lower the efficiency, but will require less time. This is described in general terms as a solid-liquid extraction, and is mathematically modeled by Fick's second law, which suggests that the rate limiting step is the diffusion of the compounds from the solid to the liquid phase (Setford et al., 2017). The maximum amount of anthocyanins that can be extracted from a given mass of calyces will typically increase with temperature, however, anthocyanins are susceptible to thermal degradation. This thermal lability has been reported in anthocyanins from diverse vegetable sources (Bolea et al., 2016, Peron et al., 2017), and further corroborated in H. sabdariffa (Sinela et al., 2017).

A functional beverage can be defined as one that exerts beneficial effects that result in a decreased risk of disease, or that has been modified by technological means to provide a benefit (Corbo et al., 2014). According to this definition, a beverage prepared from $\mathrm{H}$. sabdariffa can be considered functional when technological means are used to maximize its anthocyanin content and antioxidant activity, with the goal of minimizing the consumer's risk of disease through an increased anthocyanin intake. This can be achieved by using response surface methodology (RSM), a powerful tool that identifies interactions between the different variables, and can be used to optimize a process. RSM has been previously used to establish the best anthocyanin extraction conditions from other vegetable sources, such as black carrots (Guldiken et al., 2016), chokeberries (Simic et al., 2016), blueberry wine pomace (He et al., 2016), and numerous others. The aim of this study was to use RSM to establish the ideal conditions that would yield the highest anthocyanin content and antioxidant activity, in order to produce a high quality functional H. sabdariffa infusion.

\section{MATERIALS AND METHODS Samples and their preparation}

Commercially available dry calyces of $H$. sabdariffa cv. 'Criollo' were obtained from a local supermarket in the city of Hermosillo, in northwest Mexico. They were used to prepare infusions by varying the calyces-to-water ratio $\left(\mathrm{X}_{1}\right)$, water temperature $\left(X_{2}\right)$, and infusion time $\left(X_{3}\right)$. Calyces were carefully weighed in an analytical balance and placed in glass containers, $100 \mathrm{~mL}$ of distilled water (previously heated to the desired temperature) were then added to obtain mixtures of different calyces-to-water ratios $(\mathrm{g} / 100 \mathrm{~mL})$. The containers were left open, and placed in a heating bath with digital thermostat (1136-1D, Sold-VWR, San José, CA, USA) and the desired time (1-30 $\mathrm{min})$ and temperature (70-100
${ }^{\circ} \mathrm{C}$ ) were set. Infusion time (at a fixed temperature) was controlled with an electronic timer. A $1 \mathrm{~mL}$ aliquot of each experimental trial was diluted in $30 \mathrm{~mL}$ of aqueous methanol (8:2 methanol:water, v/v), and used to quantify total anthocyanin content (TAC) and antioxidant activity.

\section{Total anthocyanin content (TAC)}

Anthocyanins were quantified with the $\mathrm{pH}$-differential method (Lee et al., 2005). This assay is based on the chemical equilibrium that exists between the red-colored flavylium cation, and the colorless hydrated hemiketal form of the various anthocyanins, which shifts towards the former at low $\mathrm{pH}$ values. Two aliquots of each sample were prepared, one with potassium chloride solution (250 mM, pH 1.0), and the other with sodium acetate buffer $(400 \mathrm{mM}, \mathrm{pH} 4.5)$. Once mixed with each buffer, they were incubated at room temperature for $15 \mathrm{~min}$, to allow the reaction to reach equilibrium. Absorbance was then read at 510 and $700 \mathrm{~nm}$ in disposable cells ( $1 \mathrm{~cm}$ path length) using a UV-Vis spectrophotometer (Cary, model 50 Bio, Varian, Italy). Distilled water was used to set the instrument to zero. The measured absorbance was used to calculate TAC, according to Eq. 1:

$$
T A C=(A \times M W \times D F \times 1000) / \varepsilon \times l \quad \text { Eq. } 1
$$

Where, $A=\left(A_{510}-A_{700}\right)_{p H 1.0}-\left(A_{510}-A_{700}\right)_{p H 4.5^{\prime}}$ MW and $\varepsilon$ are the molecular weight $(449.2 \mathrm{~g} / \mathrm{mol})$ and molar extinction coefficient $\left(26900 \mathrm{M}^{-1} \mathrm{~cm}^{-1}\right)$, respectively, of cyanidin-3-glucoside, DF is the dilution factor, 1000 is a factor to convert $\mathrm{g}$ to $\mathrm{mg}$, and $\mathrm{I}$ is the cell's path length $(1 \mathrm{~cm})$. Results are expressed as $\mathrm{mg}$ of cyanidin-3-glucoside equivalents $/ 100 \mathrm{~mL}$ (mg C3G/100 mL) (Lee et al., 2005).

\section{Antioxidant activity}

Two different methods were used to quantify antioxidant activity, the 2,2-diphenyl-1-picrylhydrazyl (DPPH) and the 2,2'-azino-bis(3-ethylbenzothiazoline-6-sulphonic acid) (ABTS) assays. Trolox (6-hydroxy-2,5,7,8-tetramethylchroman-2-carboxylic acid) was used as standard for both assays, and results are expressed as $\mu \mathrm{mol}$ of Trolox equivalents (TE)/100 mL.

DPPH assay was performed as described by Villa-Rodríguez et al. (2011). A stock solution was prepared by dissolving $2.5 \mathrm{mg}$ of the DPPH radical in $100 \mathrm{~mL}$ of pure methanol. The absorbance of this solution was adjusted to $0.70 \pm 0.02$ (time 0 ) at $515 \mathrm{~nm}$ using a UV-VIS spectrophotometer. A 10 $\mu \mathrm{L}$ aliquot of the sample was mixed with $140 \mu \mathrm{L}$ of the DPPH solution (absorbance previously adjusted), incubated in the dark for 30 min (time 30), and its absorbance was then read at $515 \mathrm{~nm}$. Percentage of DPPH inhibition was calculated according to Eq. 2:

$$
\% \text { of DPPH inhibition }=\left[\left(A b s_{\text {time } 0}-A b s_{\text {time } 30}\right) / A b s_{\text {time } 0}\right] \times 100 \quad \text { Eq. } 2
$$

ABTS assay was performed as described by Re et al. (1999). A stock ABTS solution was prepared by mixing a 7 
$\mathrm{mM}$ ABTS solution with a $2.45 \mathrm{mM}$ sodium persulfate solution, and allowed to react in the dark at room temperature for $16 \mathrm{~h}$. Absorbance of the resulting solution was adjusted at $0.70 \pm 0.02$ (time 0 ) at $734 \mathrm{~nm}$, to yield a working solution. A $5 \mu \mathrm{L}$ aliquot of the samples was pippeted into $245 \mu \mathrm{L}$ of working solution, and absorbance was read at $734 \mathrm{~nm}$ after 6 min (time 6) of reaction. Percentage of ABTS inhibition was calculated according to Eq. 3:

$$
\% \text { of ABTS inhibition }=\left[\left(A b s_{\text {time } 0}-A b s_{\text {time } 6}\right) / A b s_{\text {timeo } 0}\right] \times 100 \text { Eq. } 3
$$

$\%$ of radical inhibition (DPPH and ABTS) were then transformed to Trolox equivalents with a standard curve of this compound, which was processed as described for the samples.

\section{Experimental design and statistical analysis}

A central composite design (CCD) was used to optimize the calyces-to-water ratio $\left(\mathrm{X}_{1}: 1-20 \mathrm{~g} / 100 \mathrm{~mL}\right)$, temperature $\left(\mathrm{X}_{2}: 70-100^{\circ} \mathrm{C}\right)$, and infusion time $\left(\mathrm{X}_{3}: 1-30 \mathrm{~min}\right)$. Coded and uncoded values of these factors, in terms of level and range, are shown in Table 1. Values were set according to conditions used in previous studies of $H$. sabdariffa beverages (Aurelio et al., 2008, Fernández-Arroyo et al., 2011, Galicia-Flores et al., 2008, Herrera-Arellano et al., 2004, Lin et al., 2007, McKay et al., 2010, Oboh and Rocha, 2008, Olatunji et al., 2005, Prenesti et al., 2007, Sáyago-Ayerdi et al., 2007, Tsai et al., 2002).

Experimental design was applied after selecting the ranges, and yielded 20 experiments. Dependent variables were TAC $\left(Y_{1}\right)$, DPPH $\left(Y_{2}\right)$, and ABTS $\left(Y_{3}\right)$. Regression analyses were performed on the experimental data, which was fitted into a second-order polynomial equation.

Table 1. Coded and uncoded factor levels used to optimize an $H$. sabdariffa infusion.

Tabla 1. Niveles codificados y no codificados de factores usados para optimizar una infusión de $H$. sabdariffa.

\begin{tabular}{lccccc}
\hline & \multicolumn{6}{c}{ Factor levels } \\
\cline { 2 - 7 } Independent variables & $\mathbf{- 1 . 6 8 2}$ & $\mathbf{- 1}$ & $\mathbf{0}$ & $\mathbf{1}$ & $\mathbf{1 . 6 8 2}$ \\
\hline $\begin{array}{l}\mathrm{X}_{1} \text { : calyces-to-water ratio } \\
(\mathrm{g} / 100 \mathrm{~mL})\end{array}$ & 1 & 4.9 & 10.5 & 16.2 & 20 \\
$\mathrm{X}_{2}$ : temperature $\left({ }^{\circ} \mathrm{C}\right)$ & 70 & 76.1 & 85 & 93.9 & 100 \\
$\mathrm{X}_{3}$ : time $(\mathrm{min})$ & 1 & 6.9 & 15.5 & 24.1 & 30 \\
\hline
\end{tabular}

The Design Expert software (Stat-Ease, Inc., Minneapolis, MN, USA) was used to perform statistical analyses and optimization process. Statistical significance of the model and regression terms were evaluated by an analysis of variance (ANOVA), and its statistical significance was confirmed by an $F$-test. Lack of fit was analyzed through an $F$-test to verify the fitness of the polynomial model equation. Results were considered significant when $\mathrm{p}<0.05$, and opposite to the lack of fit (Myer and Montgomery, 2002). Coefficient of determination $\mathrm{R}^{2}$, adjusted $\mathrm{R}^{2}\left(\mathrm{R}_{\text {Adjusted }}\right.$ ), and adequate precision were also evaluated to determine the suitability of the model. Techniques of graphical and numerical optimization were used to find the optimum levels of the independent variables. Additional confirmation experiments were subsequently conducted to verify the optimal conditions. Finally, a hypothesis testing (Student's $t$-test) was carried out to check the validation of our mathematical model using the NCSS software (NCSS, Kaysville, UT, USA).

\section{RESULTS AND DISCUSSION Response surface methodology (RSM) experiments and model fit}

We evaluated the effects of calyces-to-water ratio $\left(X_{1}\right)$, temperature $\left(\mathrm{X}_{2}\right)$, and time $\left(\mathrm{X}_{3}\right)$ on TAC and antioxidant activity of an $\mathrm{H}$. sabdariffa L. infusion. Table 2 shows the results of 20 experimental trials, which include the CCD and observed responses of TAC and antioxidant activity. This data shows that TAC ranged from $12.6-164.5 \mathrm{mg} \mathrm{C} 3 \mathrm{G} / 100 \mathrm{~mL}$, and the highest value was obtained under experimental conditions of $X_{1}=16.2 \mathrm{~g} / 100 \mathrm{~mL}, X_{2}=93.2^{\circ} \mathrm{C}$, and $X_{3}=24.1 \mathrm{~min}$.

Table 2. Central composite design (CCD) and experimental data used to optimize the total anthocyanin content (TAC) and antioxidant activity (through the DPPH and ABTS assays) of an $\mathrm{H}$. sabdariffa infusion.

Tabla 2. Diseño central compuesto (DCC) y datos experimentales utilizados para optimizar el contenido de antocianinas totales (CAT) y actividad antioxidante (mediante los métodos de DPPH y ABTS) de una infusión de $H$. sabdariffa.

\begin{tabular}{cccccccc}
\hline \multirow{2}{*}{ Run } & \multicolumn{3}{c}{ Coded variable levels } & \multicolumn{3}{c}{ Experimental values } \\
\cline { 2 - 4 } & $\mathbf{X}_{1}$ & $\mathbf{X}_{2}$ & $\mathbf{X}_{3}$ & & TAC $^{\mathbf{n}}$ & DPPH $^{\mathbf{b}}$ & ABTS $^{\mathbf{b}}$ \\
\hline 1 & -1 & -1 & -1 & 13.0 & 173.0 & 245.8 \\
\hline 2 & 1 & -1 & -1 & 50.3 & 389.4 & 796.6 \\
\hline 3 & -1 & 1 & -1 & 38.3 & 368.6 & 686.7 \\
\hline 4 & 1 & 1 & -1 & 149.5 & 811.7 & 1658.4 \\
\hline 5 & -1 & -1 & 1 & 36.8 & 473.0 & 800.8 \\
\hline 6 & 1 & -1 & 1 & 158.0 & 1051.9 & 1919.1 \\
\hline 7 & -1 & 1 & 1 & 41.5 & 502.2 & 905.1 \\
\hline 8 & 1 & 1 & 1 & 164.5 & 1096.3 & 2061.4 \\
\hline 9 & -1.682 & 0 & 0 & 12.6 & 233.0 & 418.0 \\
\hline 10 & 1.682 & 0 & 0 & 163.3 & 1075.4 & 2118.9 \\
\hline 11 & 0 & -1.682 & 0 & 32.0 & 278.0 & 428.2 \\
\hline 12 & 0 & 1.682 & 0 & 105.6 & 629.6 & 1196.0 \\
\hline 13 & 0 & 0 & -1.682 & 54.9 & 339.2 & 650.4 \\
\hline 14 & 0 & 0 & 1.682 & 140.6 & 921.4 & 1870.2 \\
\hline 15 & 0 & 0 & 0 & 136.9 & 756.2 & 1274.3 \\
\hline 16 & 0 & 0 & 0 & 123.3 & 765.8 & 1724.3 \\
\hline 17 & 0 & 0 & 0 & 136.4 & 716.2 & 1768.0 \\
\hline 18 & 0 & 0 & 0 & 134.0 & 687.2 & 1750.4 \\
19 & 0 & 0 & 0 & 130.6 & 749.1 & 1727.2 \\
20 & 0 & 0 & 0 & 123.5 & 762.1 & 1761.9 \\
\hline
\end{tabular}

$\mathrm{X}_{1}$ : calyces-to-water ratio $(\mathrm{g} / 100 \mathrm{~mL}) ; \mathrm{X}_{2}$ : temperature $\left({ }^{\circ} \mathrm{C}\right) ; \mathrm{X}_{3}$ : time $(\mathrm{min})$. Experimental data is expressed as the mean of a triplicate analysis. ${ }^{a} \mathrm{mg}$ of cyanidin-3-glucoside equivalents (C3G)/100 mL, ${ }^{\mathrm{b}} \mu \mathrm{mol}$ Trolox equivalents/100 mL.

A wide range of antioxidant activity values was found. For the DPPH assay, results ranged from 173.0-1096.3 $\mu \mathrm{mol}$ $\mathrm{TE} / 100 \mathrm{~mL}$, and for the ABTS assay $245.8-2118.9 \mu \mathrm{mol}$ TE/100 
$\mathrm{mL}$. Maximum values were found under two conditions, $X_{1}=16.2 \mathrm{~g} / 100 \mathrm{~mL}, X_{2}=93.2^{\circ} \mathrm{C}$, and $X_{3}=24.1 \mathrm{~min}$ for $\mathrm{DPPH}$, and $X_{1}=20 \mathrm{~g} / 100 \mathrm{~mL}, X_{2}=85^{\circ} \mathrm{C}$, and $X_{3}=15.5 \mathrm{~min}$ for $\mathrm{ABTS}$. An optimization process was therefore performed, in order to obtain the maximum value of the three analyzed variables.

Table 3 shows experimental data obtained from the CCD, fitted into a second order equation and analyzed through an ANOVA. According to the sequential model sum of squares, models were selected based on the highest order polynomials where the additional terms were significant and the models were not aliased (Ahmad and Alrozi, 2010). Equations 4, 5 and 6 show the fitted models in terms of coded factors for TAC, DPPH, and ABTS, respectively.

Table 3. Analysis of variance (ANOVA) for the response surface quadratic model of total anthocyanin content (TAC) and antioxidant activity (DPPH and ABTS assays).

Tabla 3. Análisis de varianza (ANOVA) del modelo cuadrático de superficie de respuesta del contenido de antocianinas totales (CAT) y capacidad antioxidante (ensayos de DPPH y ABTS).

\begin{tabular}{|c|c|c|c|c|c|c|}
\hline Variable & Source & Sum of squares & D.F. & Mean square & $F$ Value & Prob $>F$ \\
\hline \multirow{17}{*}{ TAC $^{\mathrm{a}}$} & Model & 55814.56 & 9 & 6201.62 & 54.79 & $<0.0000$ \\
\hline & $X_{1}$ & 30571.09 & 1 & 30571.09 & 270.09 & $<0.0000$ \\
\hline & $X_{2}$ & 4930.11 & 1 & 4930.11 & 43.56 & 0.0001 \\
\hline & $x_{3}$ & 6321.80 & 1 & 6321.80 & 55.85 & $<0.0000$ \\
\hline & $x_{1}^{2}$ & 3356.68 & 1 & 3356.68 & 29.66 & 0.0003 \\
\hline & $X_{2}^{2}$ & 6995.54 & 1 & 6995.54 & 61.80 & $<0.0000$ \\
\hline & $x_{3}^{2}$ & 2005.58 & 1 & 2005.58 & 17.72 & 0.0018 \\
\hline & $x_{1}^{3} x_{2}$ & 716.31 & 1 & 716.31 & 6.33 & 0.0306 \\
\hline & $x_{1} x_{3}^{2}$ & 1144.81 & 1 & 1144.81 & 10.11 & 0.0098 \\
\hline & $x_{2} x_{3}^{3}$ & 1604.61 & 1 & 1604.61 & 14.18 & 0.0037 \\
\hline & Residual & 1131.89 & 10 & 113.19 & & \\
\hline & Lack of fit & 943.50 & 5 & 188.70 & 5.01 & 0.0508 \\
\hline & Pure error & 188.39 & 5 & 37.68 & & \\
\hline & Total & 56946.45 & 19 & & & \\
\hline & $R^{2}: 0.98$ & & & & & \\
\hline & $\mathrm{R}_{\text {(Adjusted) }}: 0.96$ & & & & & \\
\hline & Adequate precision: 23.34 & & & & & \\
\hline \multirow{17}{*}{$\mathrm{DPPH}^{\mathrm{b}}$} & Model & 1511183.72 & 9 & 167909.30 & 94.40 & $<0.00001$ \\
\hline & $X_{1}$ & 773060.56 & 1 & 773060.56 & 434.63 & $<0.00001$ \\
\hline & $x_{2}$ & 120497.95 & 1 & 120497.95 & 67.75 & $<0.00001$ \\
\hline & $x_{3}$ & 407769.15 & 1 & 407769.15 & 229.26 & $<0.00001$ \\
\hline & $x_{1}^{2}$ & 6976.82 & 1 & 6976.82 & 3.92 & 0.0758 \\
\hline & $x_{2}^{2}$ & 124254.52 & 1 & 124254.52 & 69.86 & 0.0000 \\
\hline & $x_{3}^{2}$ & 13364.55 & 1 & 13364.55 & 7.51 & 0.0208 \\
\hline & $x_{1}^{3} x_{2}$ & 7314.45 & 1 & 7314.45 & 4.11 & 0.0701 \\
\hline & $\mathrm{x}_{1} \mathrm{x}_{3}^{2}$ & 32960.28 & 1 & 32960.28 & 18.53 & 0.0015 \\
\hline & $x_{2} x_{3}^{3}$ & 37032.81 & 1 & 37032.81 & 20.82 & 0.0010 \\
\hline & Residual & 17786.70 & 10 & 1778.67 & & \\
\hline & Lack of fit & 12935.05 & 5 & 2587.01 & 2.67 & 0.1528 \\
\hline & Pure error & 4851.65 & 5 & 970.33 & & \\
\hline & Total & 1528970.43 & 19 & & & \\
\hline & $R^{2}: 0.98$ & & & & & \\
\hline & $\mathrm{R}^{2}{ }_{\text {(Adjusted) }}: 0.97$ & & & & & \\
\hline & Adequate precision: 38.84 & & & & & \\
\hline \multirow{17}{*}{$A B T S^{b}$} & Model & 6958622.54 & 9 & 773180.28 & 32.09 & $<0.0000$ \\
\hline & $X_{1}$ & 3245583.12 & 1 & 3245583.12 & 134.70 & $<0.0000$ \\
\hline & $X_{2}$ & 590831.36 & 1 & 590831.36 & 24.52 & 0.0006 \\
\hline & $x_{3}$ & 1385791.53 & 1 & 1385791.53 & 57.52 & $<0.0000$ \\
\hline & $x_{1}^{2}$ & 242451.71 & 1 & 242451.71 & 10.06 & 0.0100 \\
\hline & $x_{2}^{2}$ & 1220785.46 & 1 & 1220785.46 & 50.67 & $<0.0000$ \\
\hline & $x_{3}^{2}$ & 253343.62 & 1 & 253343.62 & 10.51 & 0.0088 \\
\hline & $X_{1}^{3} X_{2}$ & 26323.65 & 1 & 26323.65 & 1.09 & 0.3205 \\
\hline & $x_{1} x_{3}^{2}$ & 70706.80 & 1 & 70706.80 & 2.93 & 0.1175 \\
\hline & $x_{2} x_{3}^{3}$ & 139418.40 & 1 & 139418.40 & 5.79 & 0.0370 \\
\hline & Residual & 240943.43 & 10 & 24094.34 & & \\
\hline & Lack of fit & 53663.04 & 5 & 10732.61 & 0.29 & 0.9018 \\
\hline & Pure error & 187280.39 & 5 & 37456.08 & & \\
\hline & Total & 7199565.97 & 19 & & & \\
\hline & $R^{2}: 0.96$ & & & & & \\
\hline & $\mathrm{R}_{\text {(Adjusted) }}: 0.93$ & & & & & \\
\hline & Adequate precision: 18.47 & & & & & \\
\hline
\end{tabular}

$\mathrm{X}_{1}$ : calyces-to-water ratio $(\mathrm{g} / 100 \mathrm{~mL}), \mathrm{X}_{2}$ : temperature $\left({ }^{\circ} \mathrm{C}\right), \mathrm{X}_{3}$ : time $(\mathrm{min}) .{ }^{\mathrm{a}} \mathrm{mg}$ of cyanidin-3-glucoside equivalents (C3G)/100 mL, ${ }^{b} \mu \mathrm{mol}$ Trolox equivalents $/ 100 \mathrm{~mL}$. 


$$
\begin{aligned}
& T A C=130.80+47.31 X_{1}+19.00 X_{2}+21.52 X_{3}-15.26 X_{1}^{2} \\
& -23.03 X_{2}^{2}-11.80 X_{3}^{2}+19.46 X_{1} X_{2}+11.96 X_{1} X_{3}-11.16 X_{2} X_{3} \text { Eq. } 4 \\
& D P P H=738.19+237.92 X_{1}+93.93 X_{2}+172.80 X_{3}-22.00 X_{1}^{2} \\
& -92.85 X_{2}^{2}-30.45 X_{3}^{2}+30.24 X_{1} X_{2}+64.19 X_{1} X_{3}-68.04 X_{2} X_{3} \text { Eq. } 5 \\
& A B T S=1665.93+485.50 X_{1}+208.00 X_{2}+318.55 X_{3}-127.71 X_{1}^{2} \\
& -219.05 X_{2}^{2}-132.59 X_{3}^{2}+57.36 X_{1} X_{2}+94.01 X_{1} X_{3}-132.01 X_{2} X_{3} \text { Eq. } 6
\end{aligned}
$$

Positive values indicate that the terms increase the response, while negative values decrease it (Martins et al., 2013). The effects of the linear terms $\left(X_{1}, X_{2}\right.$, and $\left.X_{3}\right)$ on TAC, $\mathrm{DPPH}$, and ABTS had positive coefficients, which indicates that an increase in these factors may promote an increase in TAC and antioxidant activity. The negative coefficients of the quadratic terms $\left(\mathrm{X}_{1}{ }^{2}, \mathrm{X}_{2}{ }^{2}\right.$, and $\left.\mathrm{X}_{3}{ }^{2}\right)$ and of the interaction term $\mathrm{X}_{2} \mathrm{X}_{3^{\prime}}$ indicate a possible decrease in TAC and antioxidant activity. Our data shows that the effect of the calyces-to-water ratio $\left(X_{1}\right)$ was the most critical, since it had the highest value in the obtained model. Other authors have documented similar findings, for example, Fan et al. (2008) report that the solidto-liquid ratio is the most important factor when extracting anthocyanins from purple sweet potato. Vahid Farzaneh and Carvalho (2017) also found that this was a key factor when extracting anthocyanins from Lavandula pedunculata $\mathrm{L}$.

Contribution of the studied variables to the model was significant, and they fit the model. The lack of fit tests compares the residual error to the real error from replicated design points (Senthilkumar et al., 2005). Higher values of adequate precision are desirable, since this is a measure of the signal-to-noise ratio (Garba and Rahim, 2014). Adequate precision of the studied variables was in the range of $18-38$, which suggests an adequate signal.

Coefficient of determination $\left(R^{2}\right)$ reflects the degree of fitness of a developed model, and corresponds to the ratio of variation explained for the model, with respect to total variation (Nath and Chattopadhyay, 2007). The model can properly fit the experimental data as $\mathrm{R}^{2}$ approaches unit value (Sin et al., 2006). The $\mathrm{R}^{2}$ values for Eq. 4, Eq. 5, and Eq. 6 were $>0.96$ (Table 3). This indicates that over $96 \%$ of the total variation in anthocyanin extraction, and their subsequent antioxidant activity, is attributed to the experimental variables studied. $R^{2}$ values are in reasonable agreement with the $\mathrm{R}^{2}$ Adjusted' which confirms that the model is significant. When $\mathrm{R}^{2}$ and $\mathrm{R}_{\text {Adjusted }}$ dramatically differ, there is a high probability that non-significant terms have been included in the model. The difference between $\mathrm{R}^{2}$ and $\mathrm{R}_{\text {Adjusted }}$ should ideally be $<0.2$ (Montgomery, 1997).

Most effects of the linear and quadratic terms were significant $(p<0.05)$, except for the $X_{1} X_{2}$ (solid-to-liquid ratio and temperature) interaction value $(p>0.05)$ for DPPH and ABTS. Additionally, $X_{2} X_{3}$ interaction (temperature and time) had a significant effect on all three variables, while $X_{1} X_{3}$ (solid-to-liquid ratio and time) had a significant effect only on ABTS. Our results agree with those previously reported, for example, Wong et al. (2003) report that the interaction between time and temperature was significantly related $(p<0.01)$ to anthocyanin content of an $H$. sabdariffa juice. Negative combined effects between temperature and time on anthocyanin extraction from Rubus coreanus Miq. were observed by Ku and Mun (2008). Temperature-time interaction will be further considered on the three-dimensional response surfaces and contour plots.

\section{Response surface models}

As previously mentioned, the calyces-to-water ratio had the greatest effect on the variables studied. But it is noteworthy that a high amount of calyces can impart a sour taste to the infusion, mainly due to a noticeably high concentration of organic acids, which lower its $\mathrm{pH}$ (Wong et al., 2003). In practice, H. sabdariffa infusions are usually prepared using $5 \mathrm{~g}$ of calyces in $100 \mathrm{~mL}$ of water (Bechoff et al., 2014). This variable was therefore fixed at $5 \mathrm{~g} / 100 \mathrm{~mL}$, and the threedimensional response surface and contour plots were drawn to illustrate the interactive effects of time and temperature on the response variables (Fig. 1). This interaction was significant on the three studied variables. We used graphical and numerical optimization techniques to predict the optimum levels of independent variables that would yield an infusion with the highest TAC and antioxidant activity.

\section{Response surface models for total anthocyanin content (TAC)}

Fig. $1 \mathrm{a}$ and $1 \mathrm{~b}$ show the three-dimensional response surface and contour plot of infusion temperature and time on TAC. Temperature and time have a strong influence on the stability of anthocyanins (Wong et al., 2003). In addition, both are important parameters that have to be optimized in order to minimize the energy cost of the process, particularly if done at high scales. A temperature range of $84-88^{\circ} \mathrm{C}$, and a time range of $15.5-20 \mathrm{~min}$ would yield an infusion with high TAC (71.3 mg C3G/100 mL). It is also evident that low temperatures $\left(<80^{\circ} \mathrm{C}\right)$ and short times $(6-15.5 \mathrm{~min})$, would result in a decreased TAC. This is consistent with Patras et al. (2009), who previously showed that anthocyanins in blackberry and strawberry purées were significantly affected by $2 \mathrm{~min}$ thermal treatments at $70{ }^{\circ} \mathrm{C}$. Rhim (2002) reported kinetic data of the thermal stability of anthocyanins at $70-90^{\circ} \mathrm{C}$ and Aurelio et al. (2008) found that exposure to temperatures of $>90^{\circ} \mathrm{C}$ for $120 \mathrm{~min}$ caused a gradual decrease in anthocyanin concentration. It is therefore evident that anthocyanin loss can result as a consequence of thermal treatments applied to them, which requires optimum conditions that do not induce their degradation, as has been previously documented on various compounds of vegetable origin (Domínguez Avila et al., 2018).

\section{Response surface models of antioxidant activity}

Response surfaces and contour plots for DPPH values, as a function of temperature and time, are shown in Fig. 1c 

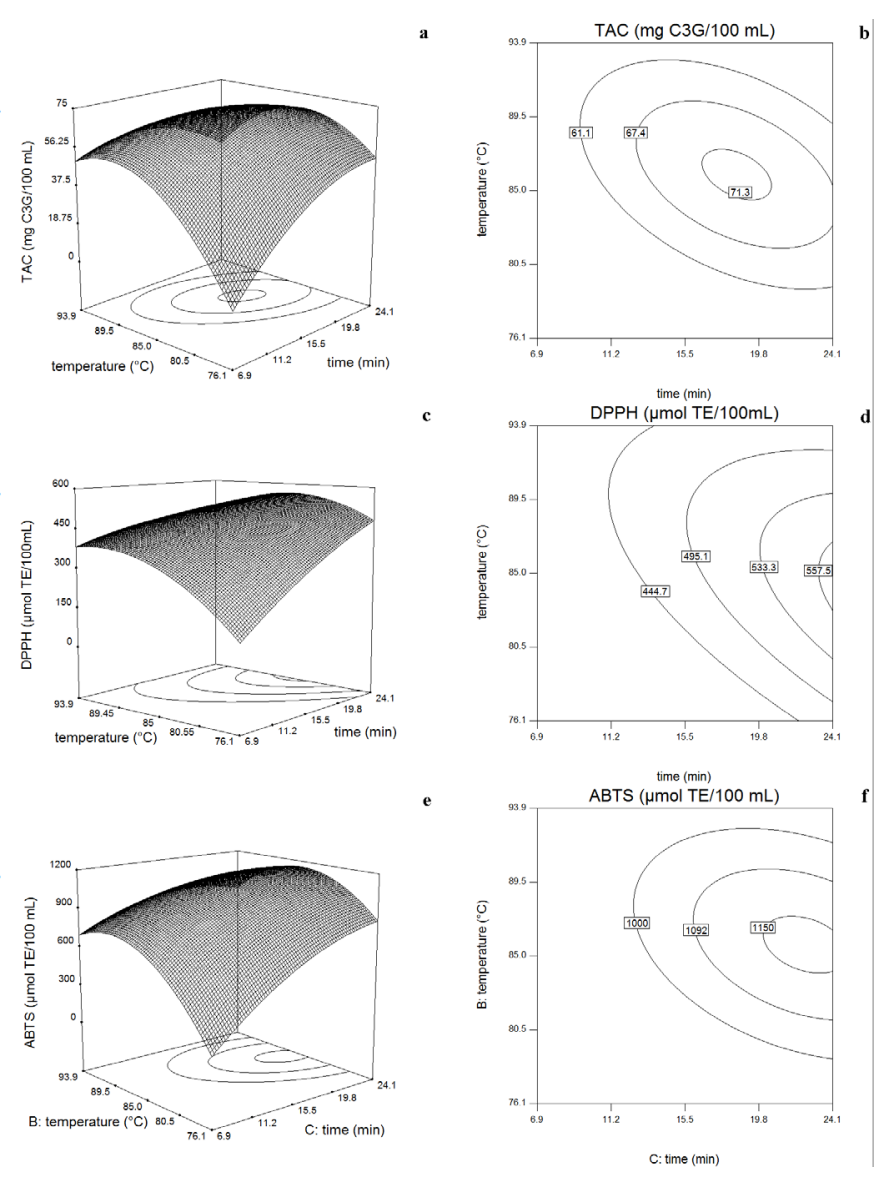

Fig. 1. Three-dimensional and contour plots for total anthocyanin content

(TAC, a and b), and antioxidant activity as measured by DPPH ( $c$ and $d$ ) and ABTS (e and $\mathrm{f}$ ) assays. All variables are analyzed as affected by varying temperature and time, while the calyces-to-water ratio was kept constant $(5 \mathrm{~g} / 100 \mathrm{~mL})$.

Fig. 1. Gráficos tridimensionales y de contorno para en contenido de antocianinas totales (CAT, a y b), y actividad antioxidante medidos por los

ensayos de DPPH (c y d) y ABTS (e y f). Todas las variables fueron analizadas de acuerdo al efecto de la temperatura y tiempo, mientras que la proporción de cálices-agua se mantuvo constante $(5 \mathrm{~g} / 100 \mathrm{~mL})$.

and Fig. 1d, respectively. Response surfaces and contour plots for ABTS values, as a function of temperature and time, are shown in Fig. 1e and 1f, respectively. Temperatures of 82-88 ${ }^{\circ} \mathrm{C}$ and times of $22-24.1 \mathrm{~min}$ increase DPPH value, while a temperature of $85^{\circ} \mathrm{C}$ and time of $23 \mathrm{~min}$ result in higher DPPH values $(557.5 \mu \mathrm{mol}$ TE/ $100 \mathrm{~mL})$. Similarly, times of $20-24.1 \mathrm{~min}$ and temperatures of $85-87^{\circ} \mathrm{C}$ had the highest ABTS values $(1165 \mu \mathrm{mol} T E / 100 \mathrm{~mL})$. The lowest temperatures and shortest time intervals would yield the lowest antioxidant activity in both methods. This trend can be expected, because low temperature would not induce anthocyanin diffusion from the solid to the liquid phase, and an equilibrium between these phases may not be reached in a short time. Other authors, such as Ramirez-Rodrigues et al. (2011) report that the highest antioxidant activity values $(1180 \mu \mathrm{mol} \mathrm{TE} / 100 \mathrm{~mL})$ of an $\mathrm{H}$. sabdariffa beverage were found when using hot water extraction $\left(90^{\circ} \mathrm{C}\right)$ and a longer extraction time (240 min).
Some authors agree with the fact that an increase in temperature enhances the extraction process, improving both the solubility of the solutes and the coefficient of diffusion (Pinelo et al., 2005; Spigno and De Faveri, 2007). However, high temperatures may not be suitable for various antioxidant compounds, because it could induce their degradation and lose their antioxidant activity (Aurelio et al., 2008; Cisse et al., 2009; Gradinaru et al., 2003). Losses in antioxidant activity of various compounds of vegetable origin are often reported following a thermal treatment, and only samples with high amounts of thermally-stable antioxidants can be extracted under increased temperature (Thoo et al., 2010; Chan et al., 2009). In fact, nonthermal processing methods may be ideal to preserve the chemical structures and bioactivities of various phytochemicals when functional beverages are being prepared (Domínguez Avila et al., 2018). This highlights once again the importance of optimizing the processing methods used when preparing functional beverages.

\section{Determination of optimal conditions and experimental validation}

Calyces-to-water ratio, temperature, and time of infusion are variables that significantly influence TAC and its subsequent antioxidant activity. Fig. 2 shows the effects of the three factors, as represented by cube plots. The cube corners show the predicted values of the coded model for the combinations of the -1 and +1 levels of the three factors (Ku and Mun, 2008). The cube model indicated that to prepare an infusion of $H$. sabdariffa, a calyces-to-water ratio $\left(\mathrm{X}_{1}\right)$ of $16.2 \mathrm{~g} / 100 \mathrm{~mL}$, a temperature $\left(\mathrm{X}_{2}\right)$ of $93.9^{\circ} \mathrm{C}$, and an infusion time $\left(X_{3}\right)$ of 24.1 min would yield desirable results. These parameters showed that the optimum anthocyanin content is $176.8 \mathrm{mg} \mathrm{C} 3 \mathrm{G} / 100 \mathrm{~mL}$, with an antioxidant activity of 1123.9 and $2146.0 \mu \mathrm{mol}$ TE/100 mL for the DPPH and ABTS assays, respectively. But as previously mentioned, a higher calyces-to-water ratio can alter the sensorial attributes, and a higher extraction time could increase the cost of the extraction process. According to these premises, the independent variables were specified into a low value, using the numerical optimization function of the Design Expert software.

Ranges for desirable conditions were set at 2.5-10 $\mathrm{g} / 100 \mathrm{~mL}$ for the calyces-to-water ratio, according to the reports of Ramirez-Rodrigues et al. (2011) and Chumsri et al. (2008). They found that ratios of 1:40 and 1:10, respectively, were suitable for a beverage with sensory attributes and physicochemical parameters similar to commercial products. Temperature range was set at $80-90^{\circ} \mathrm{C}$ and time range at 15.5-24.1 $\mathrm{min}$. These values were chosen by considering that the response surface and contour plots showed a decreased TAC and antioxidant activity when temperatures were outside of this range, and when times were shorter than 15.5 min.

Results of numerical optimization showed that the optimum combination of independent variables were a ca- 

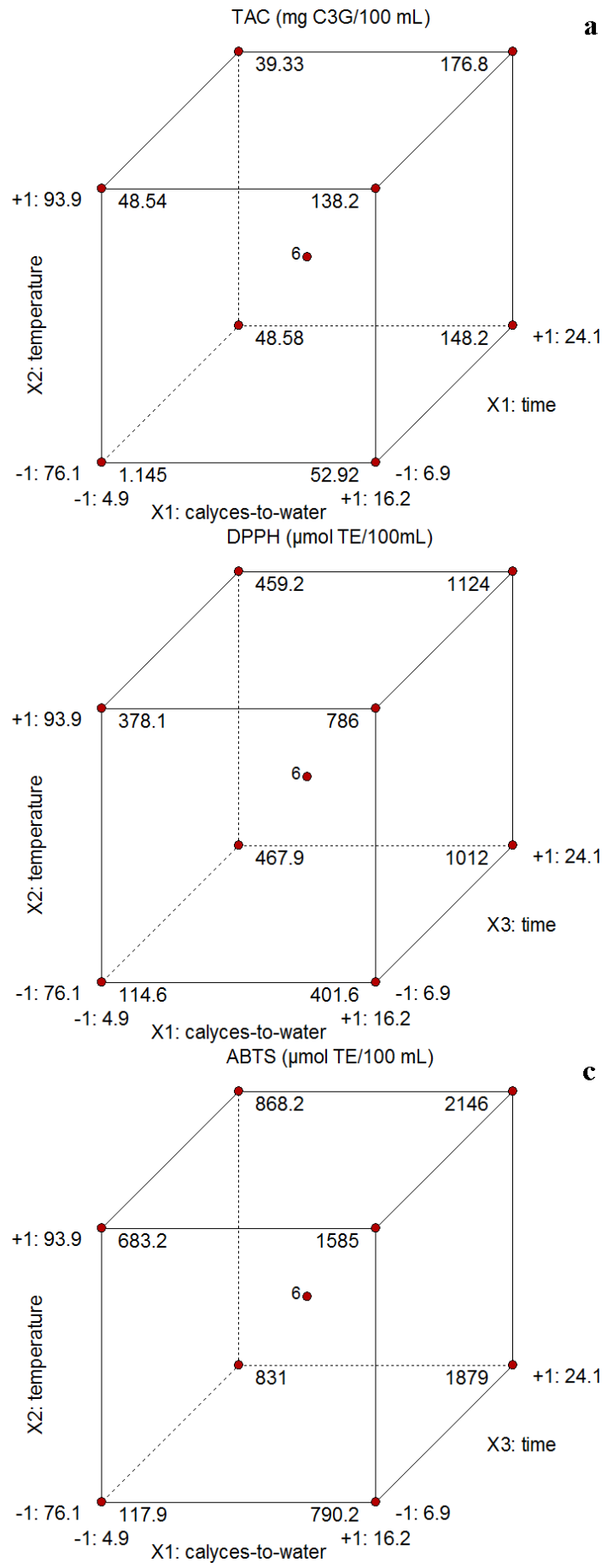

Fig. 2. Cube plots of total anthocyanin content (TAC) and antioxidant activity of $H$. sabdariffa infusions. Combined effects of the independent variables $\left(\mathrm{X}_{1}\right.$ : calyces-to-water ratio, $\mathrm{X}_{2}$ : temperature, and $\mathrm{X}_{3}$ : time), expressed from -1 to +1 , on the dependent variables a) TAC, b) DPPH, and c) ABTS.

Fig. 2. Gráficos de cubo del contenido de antocianinas totales (CAT) y actividad antioxidante de infusiones de $H$. sabdariffa. Efectos combinados de las variables independientes $\left(\mathrm{X}_{1}\right.$ : proporción cálices-agua, $\mathrm{X}_{2}$ : temperatura, y $X_{3}$ : tiempo), expresados desde -1 hasta +1 , en las variables dependientes a) TAC, b) DPPH, y c) ABTS. lyces-to-water ratio of $10 \mathrm{~g} / 100 \mathrm{~mL}$, temperature of $88.7^{\circ} \mathrm{C}$, and time of $15.5 \mathrm{~min}$. Under optimized conditions, TAC and antioxidant activity were statistically similar to predicted values, as shown in Table 4. This indicates that our model can be used to optimize anthocyanin extraction from $\mathrm{H}$. sabdariffa to produce an infusion with high antioxidant activity.

Table 4. Predicted and experimental values for total anthocyanin content (TAC), and antioxidant activity (DPPH and ABTS assays) of an $\mathrm{H}$. sabdariffa infusion prepared under optimized conditions.

Tabla 4. Valores experimentales y predichos para el contenido de antocianinas totales (CAT) y actividad antioxidante (ensayos de DPPH y ABTS) de una infusión de $H$. sabdariffa preparada bajo condiciones optimizadas.

\begin{tabular}{lcc}
\hline Independent variable & Predicted value & $\begin{array}{c}\text { Experimental } \\
\text { value* }\end{array}$ \\
\hline TAC $^{\text {a }}$ & 130.2 & $132.7 \pm 7.83(n s)$ \\
DPPH $^{\text {b }}$ & 738.8 & $800.6 \pm 69.9(n s)$ \\
ABTS $^{\text {b }}$ & 1655.9 & $1792.0 \pm 153.5(n s)$ \\
\hline
\end{tabular}

* Mean of a triplicate analysis; $(n s)=$ not significant $(p>0.05)$ between the experimental and predicted values. $X_{1}$ : calyces-to-water ratio $(g / 100 \mathrm{~mL}), X_{2}$ : temperature $\left({ }^{\circ} \mathrm{C}\right), \mathrm{X}_{3}$ : time (min). ${ }^{a} \mathrm{mg}$ of cyanidin-3-glucoside equivalents (C3G)/100 mL, ${ }^{b} \mu \mathrm{mol}$ Trolox equivalents $/ 100 \mathrm{~mL}$.

\section{CONCLUSIONS}

RSM was used to establish the parameters that would yield an optimum anthocyanin concentration and antioxidant activity from $H$. sabdariffa calyces, regarding calyces-to-water ratio, water temperature, and infusion time. Quadratic models were used to predict the responses, which were statistically validated. According to our model, $10 \mathrm{~g}$ of calyces $/ 100 \mathrm{~mL}$ of water, at a temperature of $88.7^{\circ} \mathrm{C}$, infused for $15.5 \mathrm{~min}$, would yield the most adequate results. Under these conditions, TAC was $132.7 \pm 7.83 \mathrm{mg} \mathrm{C3G/100} \mathrm{mL}$, and antioxidant activity was $800.6 \pm 69.9$ and $1792.0 \pm 153.5 \mu \mathrm{mol}$ $\mathrm{TE} / 100 \mathrm{~mL}$ for the DPPH and ABTS assays, respectively. Results showed that predicted and experimental values were similar $(p>0.05)$. Optimized parameters considered the potential sensorial characteristics of the beverage, but since this was not verified with consumers, a sensorial analysis with a panel of volunteer consumers should aid in further establishing the ideal conditions to produce a functional $H$. sabdariffa beverage.

\section{REFERENCES}

Ahmad, M. A. and Alrozi, R. 2010. Optimization of preparation conditions for mangosteen peel-based activated carbons for the removal of Remazol Brilliant Blue $\mathrm{R}$ using response surface methodology. Chemical Engineering Journal, 165, 883-890.

Ali, B. H., Cahlikova, L., Opletal, L., Karaca, T., Manoj, P., Ramkumar, A., Al Suleimani, Y. M., Al Za'abi, M., Nemmar, A., Chocholousova-Havlikova, L., Locarek, M., Siatka, T. and Blunden, G. 2017. Effect of aqueous extract and anthocyanins of calyces of Hibiscus sabdariffa (Malvaceae) in rats with adenine-induced chronic kidney disease. Journal of Pharmacy and Pharmacology, 69, 1219-1229. 
Ali, B. H., Wabel, N. A. and Blunden, G. 2005. Phytochemical, pharmacological and toxicological aspects of Hibiscus sabdariffa L.: a review. Phytotherapy Research, 19, 369-375.

Aurelio, D.-L., Edgardo, R. G. and Navarro-Galindo, S. 2008. Thermal kinetic degradation of anthocyanins in a roselle (Hibiscus sabdariffa L. cv. 'Criollo') infusion. International Journal of Food Science and Technology, 43, 322-325.

Bechoff, A., Cissé, M., Fliedel, G., Declemy, A.-L., Ayessou, N., Akissoe, N., Touré, C., Bennett, B., Pintado, M., Pallet, D. and Tomlins, K. I. 2014. Relationships between anthocyanins and other compounds and sensory acceptability of Hibiscus drinks. Food Chemistry, 148, 112-119.

Bolea, C., Turturica, M., Stanciuc, N. and Vizireanu, C. 2016. Thermal degradation kinetics of bioactive compounds from black rice flour (Oryza sativa L.) extracts. Journal of Cereal Science, 71, 160-166.

Chan, E., Lim, Y., Wong, S., Lim, K., Tan, S., Lianto, F. and Yong, M. 2009. Effects of different drying methods on the antioxidant properties of leaves and tea of ginger species. Food Chemistry, 113, 166-172.

Chiu, C. T., Chen, J. H., Chou, F. P. and Lin, H. H. 2015. Hibiscus sabdariffa Leaf Extract Inhibits Human Prostate Cancer Cell Invasion via Down-Regulation of Akt/NF-kappa B/MMP-9 Pathway. Nutrients, 7, 5065-5087.

Chumsri, P., Sirichote, A. and Itharat, A. 2008. Studies on the optimum conditions for the extraction and concentration of roselle (Hibiscus sabdariffa Linn.) extract. Songklanakarin Journal of Science and Technology, 30, 133-139.

Cisse, M., Dornier, M., Sakho, M., Ndiaye, A., Reynes, M. and Sock, O. 2009. Le bissap (Hibiscus sabdariffa L.): composition et principales utilisations. Fruits, 64, 179-193.

Corbo, M. R., Bevilacqua, A., Petruzzi, L., Casanova, F. P. and Sinigaglia, M. 2014. Functional Beverages: The Emerging Side of Functional Foods Commercial Trends, Research, and Health Implications. Comprehensive Reviews in Food Science and Food Safety, 13, 1192-1206.

Domínguez Avila, J. A., Wall Medrano, A., Ruiz Pardo, C. A., Montalvo González, E. and González Aguilar, G. A. 2018. Use of nonthermal technologies in the production of functional beverages from vegetable ingredients to preserve heatlabile phytochemicals. Journal of Food Processing and Preservation, 42, e13506.

Fan, G., Han, Y., Gu, Z. and Chen, D. 2008. Optimizing conditions for anthocyanins extraction from purple sweet potato using response surface methodology (RSM). LWT-Food Science and Technology, 41, 155-160.

Fernández-Arroyo, S., Rodríguez-Medina, I. C., Beltrán-Debón, R., Pasini, F., Joven, J., Micol, V., Segura-Carretero, A. and Fernández-Gutiérrez, A. 2011. Quantification of the polyphenolic fraction and in vitro antioxidant and in vivo anti-hyperlipemic activities of Hibiscus sabdariffa aqueous extract. Food Research International, 44, 1490-1495.

Galicia-Flores, L., Salinas-Moreno, Y., Espinoza-García, B. and Sánchez-Feria, C. 2008. Caracterización fisicoquímica y actividad antioxidante de extractos de Jamaica (Hibiscus sabdariffa L.) nacional e importada. Revista Chapingo Serie Horticultura, 14, 121-129.

Garba, Z. N. and Rahim, A. A. 2014. Process optimization of $\mathrm{K}_{2} \mathrm{C}_{2} \mathrm{O}_{4}$-activated carbon from Prosopis africana seed hulls using response surface methodology. Journal of Analytical and Applied Pyrolysis, 107, 306-312.
Gradinaru, G., Biliaderis, C. G., Kallithraka, S., Kefalas, P. and GarciaViguera, C. 2003. Thermal stability of Hibiscus sabdariffa L. anthocyanins in solution and in solid state: effects of copigmentation and glass transition. Food Chemistry, 83, 423-436.

Grajeda-Iglesias, C., Figueroa-Espinoza, M. C., Barouh, N., Barea, B., Fernandes, A., De Freitas, V. and Salas, E. 2016. Isolation and Characterization of Anthocyanins from Hibiscus sabdariffa Flowers. Journal of Natural Products, 79, 1709-1718.

Guldiken, B., Boyacioglu, D. and Capanoglu, E. 2016. Optimization of Extraction of Bioactive Compounds from Black Carrot Using Response Surface Methodology (RSM). Food Analytical Methods, 9, 1876-1886.

He, B., Zhang, L. L., Yue, X. Y., Liang, J., Jiang, J., Gao, X. L. and Yue, P. X. 2016. Optimization of Ultrasound-Assisted Extraction of phenolic compounds and anthocyanins from blueberry (Vaccinium ashei) wine pomace. Food Chemistry, 204, 70-76.

Herrera-Arellano, A., Flores-Romero, S., Chávez-Soto, M. A. and Tortoriello, J. 2004. Effectiveness and tolerability of a standardized extract from Hibiscus sabdariffa in patients with mild to moderate hypertension: a controlled and randomized clinical trial. Phytomedicine, 11, 375-382.

$\mathrm{Ku}, \mathrm{C}$. S. and Mun, S. P. 2008. Optimization of the extraction of anthocyanin from Bokbunja (Rubus coreanus Miq.) marc produced during traditional wine processing and characterization of the extracts. Bioresourse Technology, 99, 8325-8330.

Lee, J., Durst, R. W. and Wrolstad, R. E. 2005. Determination of total monomeric anthocyanin pigment content of fruit juices, beverages, natural colorants, and wines by the $\mathrm{pH}$ differential method: collaborative study. Journal of $A O A C$ International, 88, 1269-1278.

Lin, T.-L., Lin, H.-H., Chen, C.-C., Lin, M.-C., Chou, M.-C. and Wang, C.-J. 2007. Hibiscus sabdariffa extract reduces serum cholesterol in men and women. Nutrition Research, 27, 140-145.

Malacrida, A., Maggioni, D., Cassetti, A., Nicolini, G., Cavaletti, G. y Miloso, M. 2016. Antitumoral Effect of Hibiscus sabdariffa on Human Squamous Cell Carcinoma and Multiple Myeloma Cells. Nutrition and Cancer-an International Journal, 68, 1161-1170.

Martins, A. C., Bukman, L., Vargas, A. M., Barizão, É. O., Moraes, J. C., Visentainer, J. V. and Almeida, V. C. 2013. The antioxidant activity of teas measured by the FRAP method adapted to the FIA system: Optimising the conditions using the response surface methodology. Food Chemistry, 138, 574-580.

Mckay, D. L., Chen, C.-Y. O., Saltzman, E. and Blumberg, J. B. 2010. Hibiscus Sabdariffa L. Tea (Tisane) lowers blood pressure in prehypertensive and mildly hypertensive adults. The Journal of Nutrition, 140, 298-303.

Montgomery, D. C. 1997. Design and analysis of experiments, New York, Wiley.

Myer, R. and Montgomery, D. C. 2002. Response Surface Methodology: process and product optimization using designed experiment, New York, Wiley.

Nath, A. and Chattopadhyay, P. 2007. Optimization of oven toasting for improving crispness and other quality attributes of ready to eat potato-soy snack using response surface methodology. Journal of Food Engineering, 80, 1282-1292.

Oboh, G. and Rocha, J. B.T.2008. Antioxidant and neuroprotective properties of sour tea (Hibiscus sabdariffa, calyx) and green tea (Camellia sinensis) on some pro-oxidant-induced lipid peroxidation in brain in vitro. Food Biophysics, 3, 382-389. 
Olatunji, L. A., Adebayo, J. O., Oguntoye, O. B., Olatunde, N. O., Olatunji, V. A. and Soladoye, A. O. 2005. Effects of aqueous extracts of petals of red and green Hibiscus sabdariffa on plasma lipid and hematological variables in rats. Pharmaceutical Biology, 43, 471-474.

Patras, A., Brunton, N. P., Da Pieve, S. and Butler, F. 2009. Impact of high pressure processing on total antioxidant activity, phenolic, ascorbic acid, anthocyanin content and colour of strawberry and blackberry purées. Innovative Food Science and Emerging Technologies, 10, 308-313.

Peron, D. V., Fraga, S. and Antelo, F. 2017. Thermal degradation kinetics of anthocyanins extracted from jucara (Euterpe edulis Martius) and "Italia" grapes (Vitis vinifera L.), and the effect of heating on the antioxidant capacity. Food Chemistry, 232, 836-840.

Pinelo, M., Rubilar, M., Jerez, M., Sineiro, J. and Núñez, M. J. 2005. Effect of solvent, temperature, and solvent-to-solid ratio on the total phenolic content and antiradical activity of extracts from different components of grape pomace. Journal of Agricultural and Food Chemistry, 53, 2111-2117.

Prenesti, E., Berto, S., Daniele, P. G. and Toso, S. 2007. Antioxidant power quantification of decoction and cold infusions of Hibiscus sabdariffa flowers. Food Chemistry, 100, 433-438.

Ramirez-Rodrigues, M. M., Plaza, M. L., Azeredo, A., Balaban, M. O. and Marshall, M. R. 2011. Physicochemical and phytochemical properties of cold and hot water extraction from Hibiscus sabdariffa. Journal of Food Science, 76, 428-435.

Re, R., Pellegrini, N., Proteggente, A., Pannala, A., Yang, M. and Rice-Evans, C. 1999. Antioxidant activity applying an improved ABTS radical cation decolorization assay. Free Radical Biology and Medicine, 26, 1231-1237.

Rhim, J.-W. 2002. Kinetics of thermal degradation of anthocyanin pigment solutions driven from red flower cabbage. Food Science and Biotechnology, 11, 361-364.

Sáyago-Ayerdi, S. G., Arranz, S., Serrano, J. and Goñi, I. 2007. Dietary fiber content and associated antioxidant compounds in roselle flower (Hibiscus sabdariffa L.) beverage. Journal of Agricultural and Food Chemistry, 55, 7886-7890.

Senthilkumar, S. R., Ashokkumar, B., Chandra Raj, K. and Gunasekaran, P. 2005. Optimization of medium composition for alkali-stable xylanase production by Aspergillus fischeri Fxn 1 in solid-state fermentation using central composite rotary design. Bioresourse Technology, 96, 1380-1386.

Serban, C., Sahebkar, A., Ursoniu, S., Andrica, F. and Banach, M. 2015. Effect of sour tea (Hibiscus sabdariffa L.) on arterial hypertension: a systematic review and meta-analysis of randomized controlled trials. Journal of Hypertension, 33, 1119-1127.
Setford, P. C., Jeffery, D. W., Grbin, P. R. and Muhlack, R. A. 2017. Factors affecting extraction and evolution of phenolic compounds during red wine maceration and the role of process modelling. Trends in Food Science \& Technology, 69, 106-117.

Simic, V. M., Rajkovic, K. M., Stojicevic, S. S., Veliclovic, D. T., Nikolic, N. C., Lazic, M. L. and Karabegovic, I. T. 2016. Optimization of microwave-assisted extraction of total polyphenolic compounds from chokeberries by response surface methodology and artificial neural network. Separation and Purification Technology, 160, 89-97.

Sin, H. N., Yusof, S., Sheikh Abdul Hamid, N. and Rahman, R. A. 2006. Optimization of enzymatic clarification of sapodilla juice using response surface methodology. Journal of Food Engineering, 73, 313-319.

Sinela, A., Rawat, N., Mertz, C., Achir, N., Fulcrand, H. and Dornier, M. 2017. Anthocyanins degradation during storage of Hibiscus sabdariffa extract and evolution of its degradation products. Food Chemistry, 214, 234-241.

Spigno, G. and De Faveri, D. M. 2007. Antioxidants from grape stalks and marc: Influence of extraction procedure on yield, purity and antioxidant power of the extracts. Journal of Food Engineering, 78, 793-801.

Thoo, Y. Y., Ho, S. K., Liang, J. Y., Ho, C. W. and Tan, C. P. 2010. Effects of binary solvent extraction system, extraction time and extraction temperature on phenolic antioxidants and antioxidant capacity from mengkudu (Morinda citrifolia). Food Chemistry, 120, 290-295.

Tsai, P.-J., Mcintosh, J., Pearce, P., Camden, B. and Jordan, B. R. 2002. Anthocyanin and antioxidant capacity in roselle (Hibiscus Sabdariffa L.) extract. Food Research International, 35, 351-356.

Vahid Farzaneh and Carvalho, I. S. 2017. Modelling of Microwave Assisted Extraction (MAE) of Anthocyanins (TMA). Journal of Applied Research on Medicinal and Aromatic Plants, 6, 92-100.

Villa-Rodríguez, J. A., Molina-Corral, F. J., Ayala-Zavala, J. F., Olivas, G. I. and González-Aguilar, G. A. 2011. Effect of maturity stage on the content of fatty acids and antioxidant activity of 'Hass' avocado. Food Research International, 44, 1231-1237.

Wong, P. K., Yusof, S., Ghazali, H. M. and Man, C. 2003. Optimization of hot water extraction of roselle juice using response surface methodology: a comparative study with other extraction methods. Journal of the Science of Food and Agriculture, 83, 1273-1278. 